\title{
A Conversation with Sharan Merriam: Globalization and Adult Education
}

\author{
Mary Gene Saudelli \\ Dolana Mogadime \\ Nancy Taber \\ Brock University
}

On September 22, 2011, Sharan Merriam visited Brock University to give a Distinguished Speaker Lecture entitled "Globalization: Challenges and Opportunities for Adult Education." Based on her research about the future of adult education within a global context, Merriam's lecture sets the tone for this special issue on the impact of globalization for adult education and higher education. Merriam (2010) unpacked the phenomenon of globalization, connected it to the knowledge economy, and situated it within a contemporary, political, social, cultural, and educational context. Merriam (2010) highlighted the need for consideration of the trends and trajectories in adult education related to globalization as "adult education does not occur in a vacuum" (p. 408). She emphasized the need to consider research on lifelong learning that has been impacted by global education. Merriam's work further highlighted the need for the sharing of knowledge among international educators in a global context.

Subsequently, the authors of this article interviewed Merriam seeking to understand her background, how she became a specialist in adult education, her understanding of adult education as a field, and her perspective with respect to globalization and adult education. The ideas discussed in the interview led the editors to conceptualize this special issue entitled "The Impact of Globalization for Adult Education and Higher Education." This special issue seeks to explore new knowledge that considers the question: How does globalization play out within the practice of teaching adult and higher education in various adult educational contexts?

\section{Sharan Merriam, Her Story, Her Beliefs, and Vision of Globalization and Adult Education}

The focus of our interview involved three particular areas: we wanted to learn more of her background and what led her to adult education, we wanted to learn about her beliefs regarding adult education and her message to current and future adult educators, and we wanted to know her vision of adult education and the impact of globalization. We have summarized her discussions in that regard below.

\section{Her Story}

From the beginning of her career, Sharan Merriam has had a profound interest in international education. Merriam described her decision after college graduation to work with the Peace Corps, travelling to Afghanistan to teach boys English. Merriam's Afghani students were from low socioeconomic backgrounds selected for the school where she taught because they were deemed "the brightest ones in the Province." Merriam was attracted to teach abroad, both out of a desire for the sheer adventure of living in an international context that was very different from 
anything she had known but perhaps more importantly out of her sense of civic mindedness. Similar to Lovering's (2012) identification of the characteristics inspiring international educators in their rationale to go abroad, Merriam reflected on the meaning of her decision:

At the same time, that sense of adventure might make some difference. So I guess that's probably where I could trace that strain of interest throughout my career...Wanting to do something and being concerned with social issues. I guess that's maybe what drew me to adult education because of its history of social action and then making a difference in people's lives. (interview transcript)

Returning home to the United States, first teaching English to middle school children, Merriam's new journey into adult education took multifaceted and interesting roads. Initially her work with adult learners involved supporting English language communication and writing skills among American civil service workers at a training center located in Trenton, New Jersey. Conducting workshops, the knowledge areas Merriam supported were: critical thinking in business writing as well as classes in memory, concentration and interviewing. Then changing institutional learning environments to teach at an adult education centre located at Trenton State College, Merriam stayed committed to supporting language skills development but with English as a Second Language adult learners. She worked with students to prepare them to, in her own words:

Take the GED, the high school diplomacy exam, or they were just basically learning to read or write in English. So you assessed them and whatever their needs were, you would sit with them and they would have their turn doing that. So I loved that, I was really enjoying that. These people that came in were so dedicated... (interview transcript).

Throughout this time, Merriam was raising her children and continuing her own education through graduate studies at Ohio University where she earned a Master's degree in English Education. She literally "fell" into the academic field of Adult Education when seeking out a new specialization outside of English Education. As she well described it the affirmation of her interests happened through a "back door." While facilitating workshops to adults, which she "loved" doing, she serendipitously discovered adult education as a field of study via an ad for a "doctorate in adult education" (interview transcript). This was an "AHA" moment for Merriam in which she could consolidate her prior experiences and draw meaning from the wider educational theories underpinning them. Studying with respected scholars such as John Elias and Gordon Darkenwald, Merriam's work was acknowledged as noteworthy and publishable during the initial years of her doctoral studies. She went on to publish with Elias a book on Philosophical Foundations of Adult Education (1980). Both Elias and Darkenwald played a key mentoring role in Merriam's life when she was a young scholar. Merriam's scholarly work in the field of adult education is internationally recognized as influential and important.

\section{The Complexity of Adult Education}

In her discussion directly relating to the field of adult education, Merriam addressed questions about the multifaceted nature of adult education, its conceptualization as a distinct field, and its

Brock Education, 22(2), 3-10 
marginalization within universities and society. Her responses are discussed below, grouped into two main themes that are also connected to her previous work: adult education as a diverse field and challenges to adult education. This section closes with Merriam's advice to adult educators.

Adult education as a diverse field. There are multiple ways in which adult education is defined, approached, and conceived as a field. As in her own life-story, Merriam highlighted the variety of ways in which adult educators are introduced to the field of adult education, explaining that "all of us get into it through the back door" (interview transcript). Although the diversification of the field lends to its richness, adult educators have "had this problem forever: the identity issue of 'what is adult education? What is it?"' (interview transcript). People's backgrounds determine how they define adult education, because they "come at adult education from a particular angle" such as "literacy, adult basic education, or ESL,...so that's what you think adult ed is" (interview transcript). The same applies to "international work, so then you come at it from a community development perspective...or you might be in distance education, ....continuing higher education, or continuing professional education" as well as "union and labour education." There "will never be a single theory of adult learning powerful enough to capture the complexity of this phenomenon" (Merriam, 2001, p. 95).

The multifaceted nature of adult education has resulted in "multiple associations for each of these segments in the field" (interview transcript). Therefore, "it's really hard to make this umbrella called adult education work" as it has "struggled...since...it consolidated as a field" (interview transcript). Although the "practice of adult education is thriving" (Merriam \& Brockett, 2007, p. xvii, italics in original), "the profession of adult education has faced some challenges and even setbacks" (Merriam \& Brockett, 2007, p. xvii, italics in original). For instance, in the United States ${ }^{1}$, despite many successes, there have also been significant difficulties "in efforts to maintain a thriving 'umbrella' adult education association" (Merriam \& Brockett, 2007, p. 314), largely because "educators of adults tend to cluster around associations that meet the needs of their specific areas of practice" (p. 316).

Additionally, as the "vast majority of practitioners...don't realize this is a field" with its own "history and literature and research," it's "really hard for us to get funding from funding agencies because no one really understands" adult education (interview transcript). There is no "coherent structure because everybody has their own perspective and only a very small number of practitioners are in graduate programs and realize it is a field" (interview transcript). Indeed, "many educators of adults remain unaware that they are part of a cadre of thousands that constitutes the field of adult education" (Merriam \& Brockett, 2007, p. ix).

There is a "contradiction when speaking of the field of adult education" (Merriam \& Grace, 2011) in that "adult education programs are everywhere....[but] as a professional field of practice is nearly invisible" (p. xvii). There "has always been a colorful collage of various and sometimes competing components comprising adult education as a field of practice" (p. xvii). However, there are some similarities between perspectives. "Learning...is something human beings do throughout their lives" (p. xvii) and "adult education can be a positive force" (p. xvii). Additionally, "the thing that does cut across all the different components of the field is certain shared values [such as]...the respect for the adult learner,...the interest in facilitating

\footnotetext{
${ }^{1}$ Canada has faced similar challenges, but currently has a robust national association, the Canadian Association for the Study of Adult Education (CASAE).
}

Brock Education, 22(2), 3-10 
learning,...and the valuing of adults' experiences" (interview transcript). It is "the focus on the adult learner [that] is...the central key that links all of these" (interview transcript), as connected to a "wholistically" (Merriam, 2001, p. 96) determined approach to individuals, the learning process (Merriam, 2001, p. 96, italics in original), and "the context...[in which] the learning occurs" (Merriam, 2001, p. 96). Merriam ponders the idea that perhaps a "move to the notion of lifelong learning...would be better... because then that would really put the focus on what we are all about and the values that we all share" as adult educators (interview transcript). The concept of lifelong learning has "opened up our thinking of learning as broader than what goes on at school" (Merriam, Caffarella, \& Baumgartner, 2007, p. 49), even though the term has also unfortunately been used for "crass commercialization" (p. 49).

Challenges to adult education. Due to the complexity of the field, adult education faces challenges with respect to its positioning in faculties of education, the increasing presence of Human Resource Development (HRD), and a lack of overarching policies and funding opportunities. Merriam explains that most "colleges of education, don't understand adult education. They think school-based. And everywhere I've been, that's the case. And they just don't... compute that there is a whole field out there" (interview transcript). There have been various arguments for adult education to align with or distance itself from "preadult education" as a way to address its marginalization, but there are concerns that adult education would lose its distinctiveness as well as its social action approach (Merriam \& Brockett, 2007).

There are also "big tensions" (interview transcript) within the field itself, particularly with respect to Human Resource Development. HRD's "workplace profit driven, performance-based rubric is directly clashing [and] competing with... learning [focused on the] development of human potential, social commitment, social actions, [and] making lives better" (interview transcript). Merriam states that, "in all fairness, there is a growing movement in corporate-social responsibility [but]...how much of a real commitment is that? And how much of that is PR?" (interview transcript).

Merriam gave several examples of universities where a "social action adult education" focus is being displaced by "HRD folks" (interview transcript). Discussions are ongoing about changing department priorities, including making name changes that would centre on "organization development, not human development" (interview transcript). A government priority on "business and industry...[and] training" is resulting in universities changing adult education programs to "produc[e] consultants and trainers" over social advocates (interview transcript). Although Merriam thinks "HRD has its place" (see Merriam \& Brockett, 2007, for an in-depth discussion, including the ways in which HRD can engage in a societal critique), she is wary of how its behaviourist human capital tenets are "taking over" from a critical adult education approach (interview transcript). As she states in reference to any and all adult education contexts, "it is no longer a question of whether in adult learning situations we need to address issues of race, class, gender, culture, ethnicity, and sexual orientation but rather a question of how we should deal with these issues, the power dynamics involved, and so on" (Merriam, Caffarella, \& Baumgartner, 2007, p. 430, italics in original).

In a country such as the United States (as well as Canada), the lack of a national policy on adult education is disconcerting and detrimental to learning. Funding is difficult to obtain, with disparate pots of money for "work force development... literacy...housing and urban development" or to "train people to be good stewards of their community, but it's a little here

Brock Education, 22(2), 3-10 
and there, there is no umbrella, there is no national policy" so "it's left to the states or individual organizations" (interview transcript). However, it does not need to be this way, as "in other countries there are national policies" such as Singapore and Malaysia (interview transcript).

A message to adult educators. Despite these challenges, adult education is a strong field with much to offer. Merriam emphasizes the need for practitioners to have "a critical questioning eye to their practice" (interview transcript). Questions that should be continually considered include: "Why are we doing it this way? How could we do it better? What are the assumptions we [are] ...working under here?" (interview transcript). It is important to "examine what you are doing and why are you doing it this way" and avoid "technicians just doing it according to some formula. Reflective practitioners [are]... what I would like to see" who will "challenge the system" (interview transcript). For instance, much of Merriam's work (i.e., Merriam \& Associates, 2007) calls for educators to problematize the ways in which globalization and internationalization interact with learning, as well as to value and learn from non-western perspectives.

\section{Her Vision of Globalization and Adult Education}

Globalization offers tremendous opportunities and multiple challenges. When speaking of the impact of globalization and adult education, Merriam identified globalization as leading to better understandings of other conceptions of notions of learning and the nature of knowledge. She articulated that globalization offers the opportunity for reciprocity of knowledge mobilization through international adult learning relationships, and a challenge for adult educators is the complex role of language and globalization. Discussion of these ideas follow and are connected to the legacy of her work in adult education.

The nature of knowledge. The advent of globalization has provided opportunities to engage with new understandings in various contexts. Merriam believes this is enriching because we are "encountering people with all kinds of epistemological frameworks." She believes that we must encourage "valuing what each perspective has to offer" because "trying to work together on that can be good for everybody" (interview transcript). Merriam spoke of different ways to understand aspects of learning such as memory, questioning critical theory, conceptions of intellectual property, and dialogical learning that are culturally, religiously, and contextually oriented. This recognition has profound implications for how educators teach and relate with others. She emphasized the need to "decentre the privileged, Western perspective" as many other places have ways of being and ways of knowing that have "worked for them for eons" (interview transcript).

Merriam speaks to globalization as providing opportunities to reflect on what "counts" as knowledge and who "determines what 'counts"' (Merriam, 2007, p. 178) in contemporary adult education. In western contexts, knowledge is often characterized along positivistic frames of thought (Merriam, 2007; Nakashima \& Roué, 2002).This is the knowledge privileged as worthy. However, there are other "epistemological frameworks [that] have lasted over the years. It worked in that culture" (interview transcript) and Merriam believes that it is crucial for all educators to recognize and value these conceptions of knowledge. Globalization has provided a mechanism for educators to consider how we understand the nature of knowledge.

Brock Education, 22(2), 3-10 
In reflecting on what "counts" as knowledge and identity, Merriam commented on African, Asian and Indigenous conceptions of being and knowing as collectivist in orientation. Collectivist and interdependent models of identity provide opportunities to consider social place in a community. Merriam spoke of African and Asian understandings of identity as community based and making a connection to African proverbs and Confucianism (interview transcript). With issues pertaining to alienation and loneliness prevalent in many contexts but particularly identified as Western concerns (interview transcript), the notion of community identity disrupts understandings of these societal issues. In considering issues pertaining to collective efforts for social change that has occurred in various countries around the world, Merriam lauded the role of collective identity that is a historical and current ontological orientation in many international contexts. Further, Merriam identified global understandings of conceptions of community, identity and learning as important areas of exploration, research, and reflection in adult education.

Adult education and understandings of "who determines 'what counts'" is problematized with the advent of globalized educational programs. Merriam (2007) states "The hegemony of the Western 'scientific' perspective is also in evidence in the schools and universities of the nonWestern world where Western textbooks, theories and research are valued over local or regional resources" (p. 12). This represents a concern as Merriam calls for adult educators to reexamine their roles as educators in order to continue to work toward inclusive and holistic approaches. Merriam (2007, 2010) calls for adult education approaches that honour storytelling, embodied knowing, community learning, and connections to the spiritual, which are some of the ways of knowing that adult educators can learn from and incorporate into their understandings of what "counts" as knowledge in all adult education contexts (Merriam, 2007, 2010; Merriam \& Ntseane, 2008). Merriam's body of work in the past decade has highlighted the roles of nonWestern epistemologies as valuable in understanding the nature of knowledge.

The complexity of language and adult education. The complexities of language and adult education are emphasized through globalization, global communication, and the legacies of historical and contemporary colonization. Historically, colonization brought with it an educational system requiring the colonized to learn English, the language of the colonizer, with subsequent disastrous effects on the identity, traditions, and languages of the oppressed. This system of educational colonization continues to this day with the dominance of English as the language of technology, the internet, and organizations across the globe.

Merriam believes language and culture are interwoven and can be subjected to the effects of colonization particularly in relation to global education systems. She identifies that those in the academe are experiencing increasing pressure "to publish internationally [often in English] .... If I had to learn two languages it would be English and Mandarin" (interview transcript). Globally, schools, higher educational institutions, and business and governmental organizations use English as the language of communication, while indigenous and linguistically diverse languages are marginalized. Although many countries are now emphasizing a reclaiming of indigenous languages, and problematizing English as a global language, Merriam (2007) maintains that "part of the power of Western domination is linguistic" (p. 8).

Recognizing the complexity of global communication in English as a current lingua franca, Merriam cautions "that while English is a vehicle for communication with others in many different places that does not mean we have to impose our ways of doing things, our literature as

Brock Education, 22(2), 3-10 
the most legitimate source." She asserts that "reciprocity - and valuing the orientations and epistemologies of peoples globally" (interview transcript) is crucial. Regardless of whether the recognized global language remains as English in the years to come, or becomes Mandarin or some other language, adult educators will be called upon to explore and reflect on the power of the language of communication in global relationships.

\section{Final Thoughts}

The field of adult education is complex with many opportunities and challenges. As an esteemed scholar in the field, Sharan Merriam has wisdom to contribute from her story, her discussions of the field of adult education, and her vision of the field. Her call to adult educators worldwide to reflect on their educational practices and understandings speaks to the need for all educators to engage in reciprocity of learning by valuing diverse epistemologies. Sharan Merriam, a distinguished speaker indeed. 


\section{References}

Elias, J. L., \& Merriam, S. (1980). Philosophical foundations of adult education. Huntington, NY: Robert E. Krieger Publishing Co.

Lovering, M.G. (2012). Beyond the Veil: A Case Study of Context, Culture, Curriculum, and Constructivism at Dubai Women's College. (Unpublished doctoral dissertation) Brock University, Canada.

Merriam, S. (2001). Something old, something new: Adult learning theory for the twenty-first century. In S. Merriam (Ed.), The new update on adult learning theory. New Directions for Adult and Continuing Education, 89, 93-96.

Merriam, S. \& Associates. (2007). Non-western perspectives on learning and knowing. Malabar: Krieger Publishing Company.

Merriam, S. \& Brockett, R. (2007). The profession and practice of adult education: An introduction. San Francisco: John Wiley \& Sons, Inc.

Merriam, S., Caffarella, R., \& Baumgartner, L. (2007). Learning in adulthood: A comprehensive guide (3rd. ed.). San Francisco: John Wiley \& Sons, Inc.

Merriam, S. (2010). Globalization and the role of adult and continuing education: Challenges and opportunities. In C.E. Kasworm, A.D. rose, and J.M. Ross-Gordon (Eds.) Handbook of adult and continuing education (pp. 401-409). Los Angeles, CA: Sage.

Merriam, S., \& Ntseane, G. (2008). Transformational learning in Botswana: How culture shapes the process. Adult Education Quarterly, 58(3), 183-197.

Merriam, S. \& Grace, A. (2011). Preface. In S. Merriam \& A. Grace, The Jossey-Bass reader on contemporary issues in adult education (pp. xvii-xx). San Francisco: John Wiley \& Sons, Inc.

Nakashima, D.J., \& Roué, M. (2002). Indigenous knowledge, peoples and sustainable practice. In P. Timmerman's (Ed.) Encyclopedia of Global Environmental Change: Volume 5: Social and economic dimensions of global environmental change (pp 314-324). Chichester, UK: Wiley. 